\title{
Levels of selected minerals, nitric oxide, and vitamins in aborted Sakis sheep raised under semitropical conditions
}

\author{
Ismail Aytekin • Serap Unubol Aypak
}

Accepted: 27 October 2010 /Published online: 14 November 2010

(C) The Author(s) 2010. This article is published with open access at Springerlink.com

\begin{abstract}
The serum levels of calcium, phosphorus, magnesium, copper, zinc and iron and of nitric oxide, retinol, and $\beta$-carotene were determined in Sakiz ewes that had experienced an abortion and in healthy controls. Ten healthy and 25 aborted Sakiz sheep were selected from Afyon zone in western Turkey. Their ages ranged between 2 and 4 years weighing between 40 and $60 \mathrm{~kg}$ at the time of experiment. All of the abortions occurred in October. The concentrations of retinol, $\beta$-carotene, phosphorus, and zinc were significantly lower and those of calcium and nitric oxide were increased in aborted ewes relative to healthy controls. The serum levels of iron, copper, and magnesium were not significantly different among the two groups. In conclusion, abortion is an important problem in commercially important species of ruminants in many regions in the tropics including of western Turkey. Deficiencies of retinol, $\beta$-carotene, phosphorus and zinc, and the increase of calcium and nitric oxide concentration may play an important role in the etiology of abortion in ewes. Prophylactic measures such as vitamin and mineral supplementation may be of help to prevent or reduce the incidence of abortion in sheep.
\end{abstract}

Keywords Sheep · Abortion · Nitric oxide - Trace elements $\cdot$ Retinol $\cdot \mathrm{B}$-carotene

\section{Aytekin $(\square)$}

Department of Internal Medicine, Faculty of Veterinary Medicine

Mustafa Kemal University,

31040 Hatay, Turkey

e-mail: aytekinism@hotmail.com

S. U. Aypak

Department of Biochemistry, Faculty of Veterinary Medicine

Adnan Menderes University,

09016 Aydın, Turkey

\section{Introduction}

Abortion in commercially important species of sheep is a problem that derives from single or multiple factors (Hidiroglou 1979; Minson 1990). Among these, the reproductive performance of animal may be compromised by dietary deficiencies of some elements including selenium, zinc, copper and manganese, abortion, and brucellosis (Hidiroglou 1979; Minson 1990; Aytekin and Kalinbacak 2008).

The presence of abortion and brucellosis in domestic animals has been known for many years in Turkey and the world. Brucellosis is a zoonotic disease that exists worldwide and is more or less endemic in some southern European countries and still exists in most African countries (Mangen et al. 2002; John and Arimi 2002; Saegerman et al. 2008; Ibrahim et al. 2010). The diseases cause fetal membrane and abortion that have been considered as serious economic losses, causes of important fertility problems (Schelling et al. 2003; Ibrahim et al. 2010).

In Turkey, the prevalence of brucellosis has been intensively investigated in state owned cattle and sheep. Brucellosis sero-prevalences were determined $1.43 \%$ of cattle and $1.97 \%$ of sheep respectively in general Turkey (Sahin and Yildiz 2006). Brucellosis was seropositive in 29 of 145 aborted sheep and goat fetus in Thrace region west Turkey, in 74 of 238 sheep fetus in Konya (Kiran et al. 1997; Erdogan et al. 1993). In neighboring countries, brucellosis was determined as $4.84 \%(n=62)$ sheep and $7.4 \%(n=71)$ goats in Egypt (El-Ghani et al. 1984); 33.3\% $(n=471)$ sheep and goats in Greece (Giantzis et al. 1984).

Along with minerals, some vitamins such as vitamin A have been found to be important in reproductive health of cattle (Hurley and Doane 1989). Common copper deficiency 
symptoms in cattle include delayed or suppressed estrus, decreased conception, infertility, and embryo death (Corah and Ives 1991; Phillippo et al. 1987). Inadequate zinc levels have been associated with decreased fertility, abnormal estrus, abortion, and altered myometrial contractibility with prolonged labor (Duffy et al. 1977; Maas 1987). Hidiroglou (1979) and Minson (1990) suggested that there was a close link between the plasma levels of some elements and vitamins in reproductive performance and abortion in ruminants.

Nonenzymatic antioxidants include vitamin $\mathrm{C}$, vitamin $\mathrm{E}$, selenium, zinc, beta carotene, carotene, taurine, and hypotaurine. Enzymatic antioxidants include SOD, catalase, GSH-Px, glutaredoxin and glutathione reductase (Agarwal et al. 2008). Reactive oxygen species are formed endogenously during aerobic metabolism and as a result of various metabolic pathways of oocytes and embryos or as part of the body's defense mechanisms. ROS include hydroxyl radicals, superoxide anion, hydrogen peroxide, and nitric oxide (NO) (Agarwal et al. 2008). In research studies using NO inhibitors, functional impairment and damage in certain tissues were found in some cases while others found beneficial effects. Because of its effect, nitric oxide may also play a role in reproductive health (Pfister et al. 2002; Gross et al. 2004).

To date, there is insufficient information about the role of minerals, vitamins and nitric oxide, and antioxidant-oxidant status on ewe abortion.

The present study was carried out to determine the levels of calcium, phosphorus, magnesium, copper, zinc, iron, retinol, $\beta$-carotene, and nitric oxide in Sakiz sheep with abortion in Afyon zone in western Turkey.

\section{Materials and methods}

Ten healthy and 25 aborted Sakiz sheep were selected from three flocks from the Afyon region in Western Turkey. Their ages ranged between 2 and 4 years weighing between 40 and $60 \mathrm{~kg}$ at the time of experiment. All of the abortions occured in October. None of the animals included in the study were immunized.

Table 1 Levels of some elements, vitamins and nitric oxide in aborted sheep and healthy controls, in Afyon Zone, Western Turkey

\footnotetext{
NS not significant

${ }^{\mathrm{a}}$ In the same row, indicate significant differences
}

\begin{tabular}{lccc}
\hline Parameter & Controls $(n=10)$ & Abortion $(n=25)$ & $P$ value \\
\hline Calcium $(\mathrm{mg} / \mathrm{dl})$ & $12.27 \pm 0.35$ & $13.95 \pm 0.17^{\mathrm{a}}$ & $<0.05$ \\
Phosphorus $(\mathrm{mg} / \mathrm{dl})$ & $3.8 \pm 0.17$ & $2.50 \pm 0.09^{\mathrm{a}}$ & $<0.001$ \\
Magnesium $(\mathrm{mg} / \mathrm{dl})$ & $2.46 \pm 0.13$ & $2.43 \pm 0.08$ & NS \\
Iron $(\mu \mathrm{g} / \mathrm{dl})$ & $121.53 \pm 9.06$ & $120.13 \pm 5.03$ & NS \\
Copper $(\mu \mathrm{g} / \mathrm{dl})$ & $109.33 \pm 8.10$ & $130.66 \pm 7.24$ & NS \\
Zinc $(\mu \mathrm{g} / \mathrm{dl})$ & $115.01 \pm 6.05$ & $84.72 \pm 4.51^{\mathrm{a}}$ & $<0.001$ \\
Retinol $(\mu \mathrm{g} / \mathrm{dl})$ & $21.23 \pm 1.02$ & $12.66 \pm 0.29^{\mathrm{a}}$ & $<0.001$ \\
$\beta$ Carotene $(\mu \mathrm{g} / \mathrm{dl})$ & $199.72 \pm 10.13$ & $78.16 \pm 2.30^{\mathrm{a}}$ & $<0.001$ \\
Nitric oxide $(\mu \mathrm{mol} / \mathrm{L})$ & $48.44 \pm 1.25$ & $57.63 \pm 0.54^{\mathrm{a}}$ & $<0.001$ \\
\hline
\end{tabular}

None of the animals in the control group had a history of fever, loss of appetite, fatigue, abortions, and their physical examination was normal.

\section{Biochemical analysis}

Blood samples $(9 \mathrm{ml})$ were drawn from controls and subjects by jugular vein puncture into tubes without anticoagulant. After clotting, the blood samples were centrifuged at $3,000 \times \mathrm{g}$ for $10 \mathrm{~min}$ to separate the sera, which was stored at $-20^{\circ} \mathrm{C}$ until needed for analysis.

The levels of calcium, phosphorous, magnesium, iron, copper, and zinc were determined using a spectrophotometer (Perkin Elmer Model 3280, USA) using known standards from Archem, Turkey and Centronic, Germany. The NO level was established by the method of Cortas and Wakid (1990). Retinol and $\beta$-carotene were determined by the method of Suzuki and Katoh (1990).

\section{Statistical analysis}

The results are expressed as means $\pm \mathrm{SD}$. The data were analyzed with the SPSS 15.0 statistical package program (SPSS Inc, Chicago, IL, USA). An independent samples $t$ test was used to establish the statistical significance between the two groups. Statistical significance was set at $p<0.05$.

\section{Results}

The results are presented in Table 1. The levels of phosphorus, zinc, retinol, and $\beta$-carotene in the sera of aborted ewes were significantly lower and those of calcium $(p<0.05)$ and nitric oxide were higher than in the healthy controls $(p<0.001)$. The serum levels of iron, copper, and magnesium were not significantly different among the two groups. 


\section{Discussion}

Nitric oxide found the mean sera level in cattle with confirmed Brucella abortus were $65 \%$ higher than in healthy controls (Nisbet et al. 2007). Urrutia et al. (2000) reported increased NO in induced experimental infections with B. abortus and Brucella melitensis. In cases with Brucella infection, the nitrate levels were high and did not change after treatment. This increase suggests that it may be a result of the response of phagocytic cells to infection (Kandemir et al. 2002). In this study, we found significantly higher levels of NO in aborted ewes than in the controls, resulting in good agreement with literature reports (Nisbet et al. 2007; Urrutia et al. 2000; Kandemir et al. 2002)

The major reproductive problems in dairy cattle are thought to arise during late gestation, as indicated by increased rates of abortion, retained placenta stillbirths, or production of weak or blind calves (Hemken and Bremel 1982; Hurley and Doane 1989; Lotthammer and Ahlswede 1977; Lotthammer 1979). In dairy cows, deficiency of vitamin $A$ or its natural precursor, $\beta$-carotene may result in reduced conception rates (Lotthammer and Ahlswede 1977). After conception, pregnancy was maintained more efficiently in animals receiving supplemental $\beta$-carotene as indicated by decreased early embryonic mortality and early abortion rates (Lotthammer 1979). The deficiency of vitamin A in cows and ewes may cause infertility, abortion, retained placenta, blind fetus, and irregularity in sexual cycle, suboestrus, anoestrus, delayed ovulation, and increase in the rates of endometritis (Hemken and Bremel 1982; Hurley and Doane 1989). Regarding vitamin status, the levels of retinol and $\beta$-carotene were found to be significantly lower in aborted ewes than in non-aborted ewes. These results are in agreement with literature reports (Lotthammer and Ahlswede 1977; Lotthammer 1979; Hemken and Bremel 1982; Hurley and Doane 1989).

It has been reported that lower copper dietary intake of ewes either prevented implantation or induced embryonic loss and fetal death (Mcchowell 1968). Unanian and Feliciano-Silva (1984) reported that copper status was lower in aborted goats and the high incidence of early abortion may possibly be associated to copper deficiency. In addition, Anke et al. (1977) identified copper deficiency in ruminants as cause of abortion. Benzer et al. (2009) and Ekin et al. (2004) reported that serum copper levels in cattle infected with brucellosis were higher than in healthy animals. In the present case, the copper levels in aborted sheep were increased but not significantly.

Lylod et al. (1993) reported characteristic relationships between liver concentrations of some elements including phosphorus and cause of death in pre-weaned Michigan lambs. Unanian and Feliciano-Silva (1984) suggested that the high incidence of early abortion in goats could be associated with deficiencies in phosphorus. Amer (2008) and Naziroglu et al. (1998) stated that the concentration of phosphorus was significantly lower in aborted ewes than in those of healthy controls. The lower phosphorus values found in the aborted sheep in the present study are in good agreement with literature reports (Unanian and Feliciano-Silva 1984; Naziroglu et al. 1998; Amer 2008).

The beneficial effects of calcium supplementation on fertility of sheep resulted in higher conception rates (Gabryszuk and Klewiec 1996). However, the risk of abortion increased significantly in direct relationship to the serum levels of this element. Ekin et al. (2004) reported that the calcium levels of sheep with brucellosis were higher than healthy controls. The high levels of calcium found in aborted sheep possibly interfered with uptake of other minerals disturbing the gestation process (Walter et al. 2000). Contrary to expectations, the serum phosphorus levels, which are most likely to be affected by excessive calcium intake, were found to be within normal ranges (Mellado et al. 2004). Sheep with calcium levels below $8 \mathrm{mg} / \mathrm{dl}$ were half as likely to abort as those with levels higher than that. However, there are reports of goats with serum calcium $>8 \mathrm{mg} / \mathrm{dl}$ that were at an increased risk of abortion (Mellado et al. 2004). In this study, the higher calcium values were found in the aborted sheep. The significant differences between $\mathrm{Ca}$ levels of aborted ewes versus controls seem to be in good agreement with literature reports (Walter et al. 2000; Ekin et al. 2004; Mellado et al. 2004).

In conclusion, abortion is an important problem in commercially important species of ruminants in many regions of the tropics including western of Turkey. Deficiencies of retinol, $\beta$-carotene, phosphorus and zinc, and the increase of calcium and nitric oxide concentration may play an important role in the etiology of abortion in ewes. Prophylactic measures such as vitamin and mineral supplementation may be of help to prevent or reduce the incidence of abortion in sheep.

Open Access This article is distributed under the terms of the Creative Commons Attribution Noncommercial License which permits any noncommercial use, distribution, and reproduction in any medium, provided the original author(s) and source are credited.

\section{References}

Agarwal, A., Gupta, S., Sekhon, L., Shah, R., 2008. Redox considerations in female reproductive function and assisted reproduction from molecular mechanisms to health implications. Antioxid Redox Signal, 10, 1376-1388.

Amer, H.A., 2008. Some diagnostic and treatment considerations on aborted ewes. The Internet Journal of Veterinary Medicine, 4, 2. 
Anke, M., Henning, A., Grun, M., Partschefeld, M., Groppel, B., 1977. Influence of Mn, Zn, Cu, I, Se, Mo and Ni deficiencies on the fertility of ruminants. Mathematics-Naturwissensch of liche-Reihe, 26, 283-292.

Aytekin, I., Kalinbacak, A., 2008. The levels of calcium, phosphor, magnesium, copper, zinc and iron in calves eating soil in the region of Afyon. Atatürk University Journal of Veterinary Sciences, 3, 34-42.

Benzer, F., Kilic, A., Erisir, M., Ozcelik, M., Simsek, H., Temizer, Ozan P. S., 2009. Alterations in antioxidant activity and mineral levels and free radical damage in cattle infected with Brucellosis. Journal of New World Sciences Academy Veterinary Sciences, 4, 15-23.

Corah, L.R., Ives, S., 1991. The effects of essential trace minerals on reproduction in beef cattle. Veterinary Clinics of North America: Food Animal Practice, 7, 41-57.

Cortas, N.K., Wakid, N.W., 1990. Determination of inorganic nitrate in serum and urine by a kinetic cadmium-reduction method. Clinical Chemistry, 36, 1440-1443.

Duffy, J.H., Bingley, J.B., Cove L.Y., 1977. The plasma zinc concentration of nonpregnant, pregnant and parturient Hereford cattle. Australian Veterinary Journal, 53, 519-522.

El-Ghani, M.A., El-Hamed, S.A., Nada, S.M., 1984. Identification of species and biotypes of the Brucella genus in apparently healthy and aborted ewes and goats in Egypt. International Journal of Zoonose, 11, 139-144.

Ekin, S., Kozat, S., Gunduz, H., Mert, N., Karakaya, C., 2004. Levels of some trace elements and rheumatoid factor in sheep with Brucellosis. Biological Trace Element Research, 99, 123-128.

Erdogan, I., Gurel, A., Tekin, C., Uyanik, F., Bitgel, A., 1993. Sheep, goats and cattle identification and distribution of bacterial abortions in the Thrace region. The Journal of Pendik Veterinary Microbiology, 24, 23-35.

Gabryszuk, M., Klewiec, J., 1996. Effect of injecting 2- and 3-yearold ewes with calcium and magnesium on reproduction and rearing of lambs. Small Ruminant Research, 23, 151-155.

Giantzis, D., Xenos, G., Pashaleri, E., 1984. Investigation of abortion caused by infective agents in sheep and goats (in Greece). Ellenike Kteniatrike Hellenic Veterinary Medicine, 27, 132-141.

Gross, A., Bertholet, S., Mauel, J., Dornand, J., 2004. Impairment of Brucella growth in human macrophagic cells that produce nitric oxide. Microbial Pathogenesis, 36, 75-82.

Hemken, R.W., Bremel, D.H., 1982. Possible role of B-carotene in improving fertility in dairy cattle. Journal of Dairy Science, 65, 1069-1073.

Hidiroglou, M., 1979. Trace element deficiencies and fertility in ruminants; a review. Journal Dairy Science, 62, 1195-1206.

Hurley, W.L., Doane, R.M., 1989. Recent developments in the roles of vitamins and minerals in reproduction. Journal Dairy Science, 72, 784-804.

Ibrahim, N., Belihu, K., Lobago, F., Bekana, M., 2010. Seroprevalance of bovine Brucellosis and its risk factors in Jimma zone of Oramia Region, South-western Ethiopia. Tropical Animal Health Production, 42, 35-40.

John, J. M., and Arimi, S. M., 2002. Brucellosis in sub-Saharan Africa: epidemiology, control and impact. Veterinary Microbiolog, 90, 11-134.

Kandemir, O., Eskandari, G., Camdeviren, H., Sahin, E., Kaya, A., Atik, U. 2002. Plasma malondialdehyde and nitrate levels in patients with Brucellosis. Mersin Universitesi Tip Fakultesi Dergisi 3, 405-409.

Kiran, M.M., Baysal, T., Gozun, H., Guler, L., Gunduz, K., Kuyucuoglu, O., Kucukayan, U., 1997. The pathological, bacteriological and serological studies in aborted sheep in Konya region. The Journal of Etlik Veterinary Microbiolog, 9, 109-128.

Lotthammer, K.H., 1979. Importance of $\beta$-carotene for the fertility of dairy cattle. Feedstuffs, 51, 16.
Lotthammer, K.H., Ahlswede, L., 1977. Untersuchungen uber eine spezifische, Vitamin A-unabhangige wirkung des $\beta$-carotins auf die fertilitat des rindes 2. Mitt.: Weitere klinische Betunde und Befruchtungsergebnisse. Dtsch Tierarztl Wochenschr, 83, 353.

Lylod, J.W., Rook, J.S., Braselton, W.E., Shea, M.E., 1993. Relationships between liver elements concentration and cause of death in perinatal lambs in Michigan U.S.A. Preventive Veterinary Medicine, 17, 183-189.

Maas J., 1987. Relationship between nutrition and reproduction in beef cattle. Veterinary Clinics of North America: Food Animal Practice, 3, 633-646.

Mangen, M. J. Otte, J., Pfeiffer, D. and Chilonda, P., 2002. Bovine Brucellosis in sub-Saharan Africa: Estimation of Sero-prevalence and Impact on Meat and Milk Offtake Potential. FAO, Livestock Information and Policy Branch, Livestock Policy Discussion Paper No. 8, Rome, Italy.

McChowell, J.A., 1968. The effect of experimental copper deficiency on growth, reproduction and haemopoieses in the sheep. Veterinary Record, 83, 226-232.

Mellado, M., Valdez, R., Lara, L.M., Garcia, J.E., 2004. Risk factors involved in conception, abortion, and kidding rates of goats under extensive conditions. Small Ruminant Research, 55, 191-198.

Minson, D.J., 1990. Forage in ruminant nutrition. Academic Press. Inc. London.

Naziroglu, M., Cay, M., Karatas, F., Cimtay, I., Aksakal, M., 1998. Plasma levels of some vitamins and elements in aborted ewes in Elazig region. Turkish Journal of Veterinary and Animal Sicences, 22, 171-174.

Nisbet, C.,Yarim, G.F., Ciftci, A., Cenesiz, S., Ciftci, G., 2007. Investigation of serum nitric oxide and malondialdehyde levels in cattle infected with Brucella abortus. Ankara Universitesi Veteriner Fakultesi Dergisi, 54, 159-163.

Pfister, H., Remer, K.A., Brcic, M., Fatzer, R., Christen, S., Leib, S., Jungi, T.W., 2002. Inducible nitric oxide synthase and nitrotyrosine in listeric encephalitis: a cross-species study in ruminants. Veterinary Pathology, 39, 190-199.

Phillippo, M., Humphries, W.R., Atkinson, T., Henderson, G.D., Garthwaite, P.H., 1987. The effect of dietary molybdenum and iron on copper status, puberty, fertility and oestrus cycles in cattle. Journal of Agricultural Science, 109, 321-336.

Saegerman, C., Porter, S. and Humblet, M. F., 2008. Risk assessment of the re-emergence of bovine brucellosis/tuberculosis. A Paper Presented to International Colloquium on Emerging Animal Diseases, From Science to Policy, 17 October 2008, Brussels, Belgium.

Sahin, T., Yildiz, A., 2006. Seroprevalence of brucellosis in sheep and goats in Hatay region. Firat Universitesi Saglik Bilimleri Dergisi, $5,331-335$.

Schelling, E., Dinguimbaye, C., Daoud, S., Nicoletti, J., Boertin, P., Tanner, M. and Zinnstag, J., 2003. Brucellosis and Q-fever seroprevalence of nomadic pastoralists and their livestock in Chad. Preventive Veterinary Medicine, 61, 279-293.

Suzuki, J.P., Katoh, N.A., 1990. A simple and cheap methods for measuring serum vitamin $\mathrm{A}$ in cattle using only a spectrophotometer. Japanese Veterinary Science, 52, 1281-1283.

Unanian, M.D., Feliciano-Silva, A.E., 1984. Trace elements deficiency: association with early abortion in goats. International Goat and Sheep Research, 2, 129-134.

Urrutia, L.L., Alonso, A., Nieto, M.L., Bayon, Y., Orduna, A., Crespo, M.S., 2000. Lipopolysaccharides of Brucella abortus and Brucella melitensis induce nitric oxide synthesis in rat peritoneal macrophages. Infection and Immunity, 68, 1740-1745.

Walter, A., Rimbach, G., Most, E., Pallauf, J., 2000. Effects of calcium supplements to maize-soya diet on the bioavailability of minerals and trace elements and the accumulation of heavy metals in growing rats. Journal of Veterinary Medicine Series A, 47, 367-377. 